\title{
Low-temperature Nitrogen Uptake and Use of Three Cool-season Turfgrasses under Controlled Environments
}

\author{
Daniel T. Lloyd \\ Division of Plant Sciences, Turfgrass Research Center, University of Missouri, \\ 3600 East New Haven Road, Building 50, Columbia, MO 65201 \\ Douglas J. Soldat ${ }^{1}$ \\ Department of Soil Science, University of Wisconsin-Madison, 245 King Hall, \\ Madison, WI 53706 \\ John C. Stier \\ Department of Horticulture, University of Wisconsin-Madison, 381 Horticulture \\ Building, Madison, WI 53706
}

Additional index words. growth chamber, turf, lawn, fertilization

\begin{abstract}
Fall fertilization of turfgrass in northern climates is often considered to be agronomically beneficial, although research on nitrogen $(N)$ uptake during cold temperatures is sparse and environmental concerns exist regarding nitrate leaching. Therefore, the objective of this study was to evaluate $\mathrm{N}$ uptake potential, use, and plant metabolic response in a climate-controlled environment evaluating the responses of various coolseason turfgrass species to variable $\mathrm{N}$ rates and temperature regimens. Creeping bentgrass (Agrostis stolonifera L.), kentucky bluegrass (Poa pratensis L.), and annual bluegrass (Poa annua var. reptans $L$.) were seeded and grown for 3 months and then acclimated in a growth chamber to one of three climate regimens corresponding to $15 \mathrm{Sept}$., 15 Oct., and 15 Nov. in Madison, WI. Grasses were fertilized at $0,25,49$, or $98 \mathrm{~kg} \cdot \mathrm{ha}^{-1} \mathrm{~N}$ with ${ }^{15} \mathrm{~N}$-labeled ammonium sulfate $\left(10\right.$ atom $\left.\%{ }^{15} \mathrm{~N}\right)$ by applying a liquid solution of $75 \mathrm{~mL}$ per pot $(1 \mathrm{~cm}$ of solution in depth). Data collected included verdure biomass, root mass, net canopy photosynthesis, and ${ }^{15} \mathrm{~N}$ fertilizer uptake. For all turfgrass species, shoot growth increased in response to $N$ application in the September regimen, but not in October or November regimens. $N$ uptake was significantly lower in the November regimen compared with September with an average of $73 \%$ of fertilizer recovery in September compared with $57 \%$ and $38 \%$ in October and November, respectively. Root mass and net canopy photosynthesis were greatest in the November treatments, although these responses were generally unaffected by $\mathrm{N}$ application rate. The results of this study indicate that $\mathrm{N}$ uptake capacity is greatly reduced as average daily temperatures approach $0{ }^{\circ} \mathrm{C}$. Nitrogen application rates should be adjusted downward to maximize uptake efficiency in cold temperatures.
\end{abstract}

Nitrogen is the mineral nutrient required in the greatest amount for cool-season turfgrass and is often applied as fertilizer to supplement the temporally inconsistent plant-available $\mathrm{N}$ in the soil. Fertilizer $\mathrm{N}$ is applied to turfgrass at various times throughout the growing season generally totaling between $80 \mathrm{~kg} \cdot \mathrm{ha}^{-1}$ and 200 $\mathrm{kg} \cdot \mathrm{ha}^{-1}$ depending on management practices and expectations (Liu et al., 2008). Throughout temperate climates, fall is widely considered the most important time for $\mathrm{N}$ fertilization, often accounting for up to half of annual $\mathrm{N}$ applied (Bauer et al., 2012).

Received for publication 27 May 2011. Accepted for publication 29 Aug. 2011.

Funding for this project was supplied by gifts and by federal Hatch funds (Project \# WIS01346) administered by the University of Wisconsin-Madison College of Agricultural and Life Sciences.

${ }^{1}$ To whom reprint requests should be addressed; e-maildjsoldat@wisc.edu.
Many practitioners and researchers consider the ideal $\mathrm{N}$ application timing to be shortly after shoot growth ceases, a timing referred to as latefall $\mathrm{N}$ fertilization (Baird, 2007; Danneberger, 2006; Koski, 1988; Kussow, 1988; Reicher, 2005; Rieke 1997, 1998; Snow, 1982). The conventional wisdom backing this recommendation is that the cooler air temperatures in fall allow a greater portion of assimilated $\mathrm{N}$ to be used for carbohydrate accumulation and root and rhizome development instead of being partitioned into shoot growth, as has been shown to occur when temperatures are optimal for shoot growth (Bowman, 2003).

Previous research evaluating the benefits of late-fall $\mathrm{N}$ fertilization has yielded mixed results, likely as a result of regional, temporal, and climatic variability (Bauer et al., 2012). Improved color responses in the fall, winter, or spring have been observed consistently in the mid-Atlantic region (Powell et al., 1967), New England (Ledeboer and Skogley, 1973; Mangiafico and Guillard, 2006; Wilkinson and Duff, 1972), the Midwest (Miltner et al., 1996;
Walker et al., 2007; Wehner et al., 1988), and in the Pacific Northwest (Miltner et al., 2004). Root growth response to late-fall $\mathrm{N}$ fertilization has been less consistent with some researchers finding greater root mass in the fall or spring (Hanson and Juska, 1961; Moore et al., 1996), whereas others have found negative or insignificant root responses to fallapplied N (Mangiafico and Guillard, 2006; Powell et al., 1967).

The concept that turfgrass preferentially uses $\mathrm{N}$ for root and rhizome development in cool temperatures assumes sustained photosynthesis and $\mathrm{N}$ uptake and metabolism. Net photosynthesis by cool-season grasses has been shown to be higher in cooler temperatures because of diminished respiration (Powell et al., 1967), although generally photosynthesis of $\mathrm{C}_{3}$ turfgrasses follows a quadratic response with optimal photosynthesis $\approx 20{ }^{\circ} \mathrm{C}$. In perennial ryegrass (Lolium perenne $\mathrm{L}$.), a species that has relatively less cold tolerance than Agrostis spp. or kentucky bluegrass, photosynthetic rates are sensitive to chilling temperatures and can be diminished for several days after a hard chill (Moon et al., 1990). Research directly measuring turfgrass $\mathrm{N}$ uptake in cool temperatures is limited to two studies in Michigan (Frank et al., 2006; Miltner et al., 1996). Miltner et al. (1996) reported that kentucky bluegrass (Poa pratensis L.) had a $35 \% \mathrm{~N}$ uptake efficiency when $39 \mathrm{~kg} \cdot \mathrm{ha}^{-1} \mathrm{~N}$ as urea was applied on 23 Nov. after shoot growth ceased for the year. At the same research location, Frank et al. (2006) determined only $18 \%$ of $25 \mathrm{~kg} \cdot \mathrm{ha}^{-1} \mathrm{~N}$ applied as urea was taken up by kentucky bluegrass when applied on 17 Oct. The differences between the two studies at the same location with the same grass highlight the large variability that can be observed in field research as a result of weather and edaphic factors. Uncertainty remains regarding capacity for turfgrass to assimilate $\mathrm{N}$ in the late fall, although for many other plants, researchers have shown that $\mathrm{N}$ uptake is greatly inhibited in temperatures below those of optimal growth resulting from limited xylem flow and downregulated transporters responding to decreased plant demand (Dubey and Pessarakli, 2002).

The extent to which $\mathrm{N}$ uptake by turfgrass is inhibited by low temperature likely depends on environmental factors and turfgrass species. High rates of $\mathrm{N}$ fertilization during a time when turfgrass uptake and $\mathrm{N}$ immobilization decline increases the likelihood of fertilizer loss through denitrification and leaching, especially considering the high precipitation and low evapotranspiration (ET) rates characteristic of late fall in many parts of the temperate United States. Excess $\mathrm{N}$ fertilization at this time is a potential economic and environmental burden.

Additional research evaluating fall-applied $\mathrm{N}$ uptake and use by cool-season turfgrass is warranted because of a potential disconnect between environmental interests and perceived agronomic benefits through the often emphasized practice of late-fall $\mathrm{N}$ fertilization. Much of the research performed on late-fall $\mathrm{N}$ fertilization was performed in field settings, which may limit the transferability of the results resulting from regional, climatic, and site-specific 
variables. In fact, no controlled environment research could be found evaluating lowtemperature $\mathrm{N}$ uptake, metabolism, and use of turfgrass or the response differences among $\mathrm{N}$ rate, application timing, and turfgrass species in cool temperatures. As a result of the perceived importance of fall fertilization, the agronomic significance should be evaluated through controlled environment research accounting for climatic and spatial variables such as temperature, photoperiod, $\mathrm{N}$ rate, and turfgrass species composition. Therefore, the objective of this study was to evaluate $\mathrm{N}$ uptake potential, use, and plant metabolic response in a climatecontrolled environment evaluating the responses of various cool-season turfgrass species to variable $\mathrm{N}$ rates and temperature regimens.

\section{Materials and Methods}

'Midnight' kentucky bluegrass, 'Penncross' creeping bentgrass (Agrostis stolonifera L.), and 'True Putt' annual bluegrass (Poa annua var. reptans L.) were established from seed at the rate of three pure live seeds $/ \mathrm{cm}^{2}$ in a greenhouse set to $24 / 18{ }^{\circ} \mathrm{C}$ day/night temperatures with a photoperiod of $14 \mathrm{~h}$. Plants were grown in $10-\mathrm{cm}$ diameter polyvinyl chloride pipe cut to $30 \mathrm{~cm}$ depth, outfitted with a drain cap base, then filled with $85: 15(\mathrm{v} / \mathrm{v})$ sand to peat root zone mix conforming to USGA specifications (Green Section Staff, 2004) and packed incrementally to a bulk density of $1.4 \mathrm{~g} \cdot \mathrm{cm}^{-3}$. Plants were fertilized using a granular $14 \mathrm{~N}-$ $12.3 \mathrm{P}-10 \mathrm{~K}$ product, which included urea, monoammonium phosphate, and methylene urea as $\mathrm{N}$ sources at the rate of $49 \mathrm{~kg} \cdot \mathrm{ha}^{-1} \mathrm{~N}$ during seeding. Additional nutrients were supplied at 4 and 8 weeks after seeding using a mix of ammonium sulfate and potassium phosphate at the rate of $25 \mathrm{~kg} \cdot \mathrm{ha}^{-1} \mathrm{~N}, 25 \mathrm{~kg} \cdot \mathrm{ha}^{-1}$ potassium, and $20 \mathrm{~kg} \cdot \mathrm{ha}^{-1}$ phosphorus. Irrigation was applied daily in a mist house for $14 \mathrm{~d}$ after seeding and three times weekly thereafter at $35 \mathrm{~mm} /$ week. Plants were clipped using hand shears three times weekly to the height of $13 \mathrm{~mm}$ until $\mathrm{N}$ treatments were applied. Fourteen weeks after seeding, the plants were transferred from the greenhouse into a growth chamber for cool temperature acclimation.

The three grass species were fertilized with one of four $\mathrm{N}$ treatments $(0,24.5,49$, and $98 \mathrm{~kg}$ $\mathrm{N} / \mathrm{ha}$ ) and acclimated to one of three simulated climate regimens corresponding to 15 Sept., 15 Oct., and 15 Nov. in Madison, WI, based on the 40-yr averages (Table 1). Three units of each grass type and $\mathrm{N}$ treatment were arranged in a completely randomized design in climatecontrolled chambers at the University of Wisconsin-Madison Biotron Facility. Each of the three climate regimens were conducted in the same growth chamber at different times. The experiment was conducted twice under identical conditions. On entering the growth chamber, plants were allowed to acclimate for $16 \mathrm{~d}$ through staggered decreasing temperature regimens, where the temperature was lowered by $1.3{ }^{\circ} \mathrm{C}$, and $2.7^{\circ} \mathrm{C}$ every $4 \mathrm{~d}$ until temperature reached the appropriate set points for the October and November regimens, respectively. The September treatments did not require an acclimation stage. Temperature regimens and photoperiod are outlined in Table 1. After the acclimation period, plants were fertilized with one of the four $\mathrm{N}$ rates using a liquid solution of ${ }^{15} \mathrm{~N}$-labeled ammonium sulfate (10 atom \% $\left.{ }^{15} \mathrm{~N}\right)$. After labeled $\mathrm{N}$ was applied, plants were irrigated to $80 \%$ of pot moisture capacity based on weight to eliminate the potential for leaching losses.

Seven $\mathrm{d}$ after $\mathrm{N}$ treatment, net ecosystem $\mathrm{CO}_{2}$ exchange (NEE) was determined by calculating the difference of $\mathrm{CO}_{2}$ fixation from the turf canopy and respiration from the turf + soil ecosystem. Photosynthesis can be approximated from NEE values, but NEE more accurately provides a measure of plant and microbial metabolic response to $\mathrm{N}$ fertilization and temperature. An infrared gas analyzer with a modified canopy chamber provided with 500 $\mu \mathrm{mol} \cdot \mathrm{m}^{-2} \cdot \mathrm{s}^{-2} \mathrm{CO}_{2}$ was used to determine $\mathrm{CO}_{2}$ exchange rates (LI-COR 6400; Li-COR, Inc., Lincoln, NE). The 1-L custom canopy chamber (10 cm height, $10 \mathrm{~cm}$ diameter) consisted of a clear acrylic cylinder to allow light transmission with a ring around the base to form a seal on top of polyvinyl chloride columns. The mixing fan installed in the infrared gas analyzer was sufficient for mixing the chamber volume on factory settings. The chamber was allowed to equilibrate for exactly $5 \mathrm{~min}$ before photosynthesis measurements were recorded. Gas exchange measurements were recorded between 1100 and 1400 HR; canopy temperature and photosynthetically active radiation $(P A R)$ were also recorded.

Before $\mathrm{N}$ applications, all plants were cut to $13 \mathrm{~mm}$ and allowed to grow unclipped until harvested. Plants were watered three times weekly to $80 \%$ of pot water-holding capacity to prevent moisture stress. Plants were destructively harvested $10 \mathrm{~d}$ after $\mathrm{N}$ applications. On harvest, soil columns were split lengthwise using a custom-designed stainless steel blade and intact halves were removed from the polyvinyl chloride pipe. One half was used for soil analysis, whereas the other half was used to quantify root biomass. Verdure from each column was removed at the soil surface using a razor blade and then dried at $60^{\circ} \mathrm{C}$ for $24 \mathrm{~h}$. Dried samples were cleaned of sand and debris using the vibrating pan method (Kreuser et al., 2011). Cleaned samples were then weighed to determine verdure mass.

After verdure was removed, the soil column was dried at $60^{\circ} \mathrm{C}$ for $48 \mathrm{~h}$. After drying, the roots were separated from the root zone mix using a dry sieving technique. Peat was removed from the root samples using forceps and fine roots shed during this process were collected on an aluminum baking pan and added into the mass. Debris was discarded and clean root samples were weighed.

Dried and cleaned verdure and root samples were ground using a Wiley mill (Thomas

Table 1. Growth chamber conditions recorded for second run of cool-season grass response to September, October, and November temperature regimens. ${ }^{\mathrm{z}}$

\begin{tabular}{|c|c|c|c|c|c|c|}
\hline \multirow{3}{*}{$\begin{array}{l}\text { Temp. } \\
\text { regimen }\end{array}$} & \multicolumn{3}{|c|}{ Growth chamber temp. } & \multirow{3}{*}{$\begin{array}{c}P A R \\
\left(\mu \mathrm{mol} \cdot \mathrm{m}^{-2} \cdot \mathrm{s}^{-1}\right)\end{array}$} & \multirow{3}{*}{$\begin{array}{c}\mathrm{CO}_{2} \\
\left(\mu \mathrm{L} \cdot \mathrm{L}^{-1}\right)\end{array}$} & \multirow{3}{*}{$\begin{array}{l}\text { Photoperiod } \\
\left(\mathrm{h} \cdot \mathrm{d}^{-1}\right)\end{array}$} \\
\hline & Mean daily & Minimum & Maximum & & & \\
\hline & \multicolumn{3}{|c|}{ 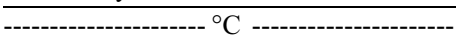 } & & & \\
\hline September & 16.1 & $10.9(11)$ & $22.7(19)$ & 431 & 409 & $12.5(12.5)$ \\
\hline October & 11.3 & $6.9(6)$ & $15.1(14)$ & 466 & 380 & $11.0(11.0)$ \\
\hline November & 1.8 & $-2.7(-3)$ & $4.6(5)$ & 405 & 397 & $9.6(9.6)$ \\
\hline
\end{tabular}

${ }^{\mathrm{z}}$ Chamber set points are presented in parentheses. $P A R$ and $\mathrm{CO}_{2}$ values reported are means of each regimen. Diurnal temperature set points did not deviate by more than $2^{\circ} \mathrm{C}$ in 3 -h intervals.

${ }^{\text {y }}$ Temperature regimens were chosen to correspond to 40 -year means of 15 Sept., 15 Oct., and 15 Nov. for Madison, WI.

$P A R=$ photosynthetically active radiation

Table 2. $P$ values from analysis of variance for treatment effects on plant and soil response parameters. ${ }^{\mathrm{z}}$

\begin{tabular}{|c|c|c|c|c|c|}
\hline $\begin{array}{l}\text { Source of } \\
\text { variation }\end{array}$ & df & Verdure biomass & Root mass & $\mathrm{df}$ & Total ${ }^{15} \mathrm{~N}$ uptake \\
\hline & & \multicolumn{4}{|c|}{ Run 1} \\
\hline Temp. (T) & 2 & $0.014 *$ & $<0.001 * * *$ & 2 & $<0.001 * * *$ \\
\hline $\mathrm{N}$ rate $(\mathrm{N})$ & 3 & $0.004 * *$ & $0.007 * *$ & 2 & $<0.001 * * *$ \\
\hline Species (S) & 2 & $<0.001 * * *$ & $<0.001 * * *$ & 2 & 0.195 \\
\hline $\mathrm{T} \times \mathrm{N}$ & 6 & $<0.001 * * *$ & $0.01 * *$ & 4 & $0.028 *$ \\
\hline $\mathrm{T} \times \mathrm{S}$ & 4 & 0.122 & $<0.001 * * *$ & 4 & 0.841 \\
\hline $\mathrm{N} \times \mathrm{S}$ & 6 & 0.114 & 0.112 & 4 & 0.393 \\
\hline \multirow[t]{2}{*}{$\mathrm{T} \times \mathrm{N} \times \mathrm{S}$} & 12 & 0.085 & 0.137 & 8 & 0.375 \\
\hline & & \multicolumn{4}{|c|}{ Run 2} \\
\hline Temp. (T) & 2 & $<0.001 * * *$ & $0.040^{*}$ & 2 & $<0.001 * * *$ \\
\hline N Rate $(\mathrm{N})$ & 3 & $0.004 * *$ & 0.940 & 2 & $0.002 * *$ \\
\hline Species (S) & 2 & $<0.001 * * *$ & $<0.001 * * *$ & 2 & $0.033^{*}$ \\
\hline $\mathrm{T} \times \mathrm{N}$ & 6 & $<0.001 * * *$ & 0.263 & 4 & $0.024 *$ \\
\hline $\mathrm{T} \times \mathrm{S}$ & 4 & $0.002 * *$ & $<0.001 * * *$ & 4 & 0.675 \\
\hline $\mathrm{N} \times \mathrm{S}$ & 6 & 0.169 & 0.064 & 4 & 0.662 \\
\hline $\mathrm{T} \times \mathrm{N} \times \mathrm{S}$ & 12 & 0.062 & 0.119 & 8 & 0.395 \\
\hline
\end{tabular}

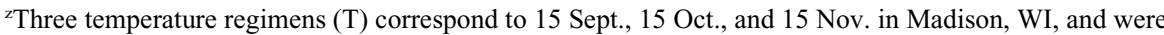
each replicated in a separate run. Four nitrogen rates $(\mathrm{N})$ were applied $\left(0,25,49\right.$, and $\left.98 \mathrm{~kg} \cdot \mathrm{ha}^{-1}\right)$ to three turfgrass species (S) (creeping bentgrass, kentucky bluegrass, annual bluegrass).

$*, * *, * * *$ Significant at the $0.05,0.01$, and $0.001 P$ level, respectively. 
Scientific, Swedesboro, NJ) to pass through a $0.25-\mathrm{mm}$ sieve and packaged in tin capsules to contain 100 to $200 \mu \mathrm{g} \mathrm{N}$ for isotopic ${ }^{15} \mathrm{~N}$ analysis using an automated carbon-nitrogen analyzer (PDZ-Europa, Crewe, U.K.).

The experiment was a completely randomized design of a four $(\mathrm{N}) \times$ three (temperature) $\times$ three (species) factorial with three replications. The factorial experiment was conducted twice, in separate "runs," which were treated similarly to a year or location effect in the statistical model. Because the "run" was a statistically significant main effect for all responses except net ecosystem exchange rate, we analyzed and presented the data separately for each run. Runs were combined for net ecosystem exchange. The statistical software JMP (Version 8; SAS Institute, Cary, NC) was used for analysis of variance. When appropriate, treatment means were separated by Tukey's honestly significant difference test at the 0.05 level. Data were log (base 10) transformed whenever residuals were not normally distributed.

\section{Results}

Growth chamber conditions, including temperature, light intensity, $\mathrm{CO}_{2}$ concentrations, and humidity, were continually monitored through computerized sensors and did not deviate substantially from the set points

Table 3. Verdure biomass as affected by temperature regimen and nitrogen application rate. ${ }^{z}$

\begin{tabular}{ccccc}
\hline & \multicolumn{4}{c}{ Nitrogen application rate } \\
\cline { 2 - 5 } Timing & $\begin{array}{c}0 \\
\mathrm{~kg} \cdot \mathrm{ha}^{-1}\end{array}$ & $\begin{array}{c}24.5 \\
\mathrm{~kg} \cdot \mathrm{ha}^{-1}\end{array}$ & $\begin{array}{c}48.9 \\
\mathrm{~kg} \cdot \mathrm{ha}^{-1}\end{array}$ & $\begin{array}{c}96 \\
\mathrm{~kg} \cdot \mathrm{ha}^{-1}\end{array}$ \\
\hline Run 1 & \multicolumn{4}{c}{$\mathrm{m}^{-2}$} \\
Sept. & $178 \mathrm{C}$ & $240 \mathrm{~B}$ & $254 \mathrm{AB}$ & $306 \mathrm{~A}$ \\
Oct. & $225 \mathrm{BC}$ & $217 \mathrm{BC}$ & $225 \mathrm{BC}$ & $217 \mathrm{BC}$ \\
Nov. & $217 \mathrm{BC}$ & $220 \mathrm{BC}$ & $227 \mathrm{BC}$ & $240 \mathrm{BC}$ \\
& & & \\
Run 2 & & & \\
Sept. & $249 \mathrm{CD}$ & $277 \mathrm{BC}$ & $321 \mathrm{AB}$ & $348 \mathrm{~A}$ \\
Oct. & $215 \mathrm{DE}$ & $220 \mathrm{DE}$ & $232 \mathrm{CDE}$ & $235 \mathrm{CDE}$ \\
Nov. & $183 \mathrm{EF}$ & $188 \mathrm{EF}$ & $185 \mathrm{EF}$ & $158 \mathrm{~F}$ \\
\hline
\end{tabular}

${ }^{2}$ Verdure was harvested $10 \mathrm{~d}$ after nitrogen application. Temperature regimens correspond to 15 Sept., 15 Oct., and 15 Nov. in Madison, WI. Different letters within runs indicate statistical significance at the 0.05 level according to Tukey's honestly significant difference.

Table 4. Verdure biomass as affected by temperature regimen and turf species. ${ }^{z}$

\begin{tabular}{|c|c|c|c|}
\hline Timing & $\begin{array}{l}\text { Creeping } \\
\text { bentgrass }\end{array}$ & $\begin{array}{l}\text { Kentucky } \\
\text { bluegrass }\end{array}$ & $\begin{array}{c}\text { Annual } \\
\text { bluegrass }\end{array}$ \\
\hline Run 1 & & $g \cdot m^{-2}$ & \\
\hline Sept. & $284 \mathrm{~A}$ & $193 \mathrm{CD}$ & $257 \mathrm{AB}$ \\
\hline Oct. & $245 \mathrm{AB}$ & $188 \mathrm{CD}$ & $235 \mathrm{ABC}$ \\
\hline Nov. & $227 \mathrm{BCD}$ & $180 \mathrm{D}$ & $254 \mathrm{AB}$ \\
\hline
\end{tabular}

Run 2

$\begin{array}{llll}\text { Sept. } & 299 \mathrm{AB} & 269 \mathrm{BC} & 329 \mathrm{~A} \\ \text { Oct. } & 245 \mathrm{C} & 188 \mathrm{D} & 245 \mathrm{C} \\ \text { Nov. } & 161 \mathrm{D} & 183 \mathrm{D} & 188 \mathrm{D}\end{array}$

${ }^{\mathrm{z}}$ Temperature regimens correspond to 15 Sept., 15 Oct., and 15 Nov. in Madison, WI. Different letters within runs indicate statistical significance at the 0.05 level according to Tukey's honestly significant difference.
(Table 1). The environmental data from the first run of each temperature regimen were prematurely deleted by the system operator and are therefore unavailable, although realtime inspection of the data during the experiment showed consistency with the set points. $P A R$ and $\mathrm{CO}_{2}$ concentrations were consistent for all temperature regimens and runs, averaging $426 \pm 40 \mu \mathrm{mol} \cdot \mathrm{m}^{-2} \cdot \mathrm{s}^{-1}$ and $396 \pm 39$ $\mu \mathrm{L} \cdot \mathrm{L}^{-1}$, respectively.

Verdure biomass was significantly affected by all three main effects: temperature regimen, $\mathrm{N}$ rate, and species in both runs (Table 2 ). Also, the temperature-by-N interaction was significant in both runs, whereas the temperature-by-species interaction was significant in the second run only. Growth response to $\mathrm{N}$ was only observed for the September timing with no differences in growth observed within October or November temperature regimens as a result of $\mathrm{N}$ application from 0 to $96 \mathrm{~kg} \cdot \mathrm{ha}^{-1}$ (Table 3). In general, kentucky bluegrass produced the least amount of verdure biomass, often significantly lower than the other grasses, especially in the September and October timings (Table 4). Creeping bentgrass and annual bluegrass had statistically similar verdure biomass within temperature regimens. For all three grasses, there was a more pronounced decrease in verdure biomass as temperature decreased in Run 2 compared with Run 1 (Table 4).

For root mass, the main effects of temperature and species were highly significant, whereas the effect of $\mathrm{N}$ rate was not consistent (Table 2). In Run 1, the lowest root mass measurements were associated with the highest two application rates in the September and October temperature regimens. The greatest root mass was associated with the November temperature regimen across all $\mathrm{N}$ rates. However, in Run 2, $\mathrm{N}$ did not affect root mass (Table 5). Across $\mathrm{N}$ rates, creeping bentgrass had the greatest root mass and was statistically greater than kentucky bluegrass in all temperature regimens (Table 6). Bentgrass had statistically greater root mass than annual bluegrass in the September regimen and in Run 1 of the October regimen. Annual bluegrass had greater root mass than kentucky bluegrass in the November regimens of both runs and for the September regimen of Run 1 (Table 6). With the exception of kentucky bluegrass in Run 2, there was a strong trend of increasing root mass with decreasing temperature.

Table 5. Root biomass as affected by temperature regimen and nitrogen application rate. ${ }^{\mathrm{z}}$

\begin{tabular}{lllll}
\hline & \multicolumn{4}{c}{ Nitrogen application rate } \\
\cline { 2 - 5 } Timing & $0 \mathrm{~kg} \cdot \mathrm{ha}^{-1}$ & $24.5 \mathrm{~kg} \cdot \mathrm{ha}^{-1}$ & $49.0 \mathrm{~kg} \cdot \mathrm{ha}^{-1}$ & $98 \mathrm{~kg} \cdot \mathrm{ha}^{-1}$ \\
\hline Run 1 & $192 \mathrm{CDEF}$ & $220 \mathrm{BCDEF}$ & $179 \mathrm{EF}$ & $159 \mathrm{~F}$ \\
Sept. & $231 \mathrm{ABCDE}$ & $179 \mathrm{EF}$ & $183 \mathrm{DEF}$ & $159 \mathrm{~F}$ \\
Oct. & $253 \mathrm{ABC}$ & $227 \mathrm{AB}$ & $318 \mathrm{~A}$ & $253 \mathrm{ABCD}$ \\
Nov. & & & \\
& & $220 \mathrm{~A}$ & $215 \mathrm{~A}$ \\
Run 2 & $231 \mathrm{~A}$ & $253 \mathrm{~A}$ & $247 \mathrm{~A}$ & $271 \mathrm{~A}$ \\
Sept. & $271 \mathrm{~A}$ & $247 \mathrm{~A}$ & $259 \mathrm{~A}$ & $247 \mathrm{~A}$ \\
Oct. & $247 \mathrm{~A}$ & $210 \mathrm{~A}$ & & \\
Nov. & & & & \\
\hline
\end{tabular}

${ }^{\mathrm{z}}$ Temperature regimens correspond to 15 Sept., 15 Oct., and 15 Nov. in Madison, WI. Roots were harvested $10 \mathrm{~d}$ after nitrogen application. Different letters within runs indicate statistical significance at the 0.05 level of log-transformed values according to Tukey's honestly significant difference.
${ }^{15} \mathrm{~N}$ fertilizer uptake was significantly affected by temperature regimen and $\mathrm{N}$ rate in both runs and by species in Run 2 (Table 2). The temperature-by- $\mathrm{N}$ rate interaction was also statistically significant in both runs. The September treatments recovered $\approx 80 \%$ of the applied ${ }^{15} \mathrm{~N}$ in Run 1 and $\approx 70 \%$ of applied ${ }^{15} \mathrm{~N}$ regardless of application rate (Fig. 1). Within temperature regimens, no statistical differences were observed in ${ }^{15} \mathrm{~N}$ uptake. In Run 1 , ${ }^{15} \mathrm{~N}$ uptake in the September regimen was greater than the November regimen only at the $98 \mathrm{~kg} \cdot \mathrm{ha}^{-1}$ rate, whereas in Run $2,{ }^{15} \mathrm{~N}$ uptake during the September regimen was greater than the November regimen regardless of $\mathrm{N}$ rate. The October regimen had intermediate ${ }^{15} \mathrm{~N}$ uptake, often statistically similar to both the September and November regimens (Fig. 1).

Root accumulation of ${ }^{15} \mathrm{~N}$ was markedly different between runs. In the first run, we observed significantly greater recovery of ${ }^{15} \mathrm{~N}$ in the November regimen compared with the September and October regimens (Fig. 1A). However, the opposite occurred in Run 2 (Fig. 1B). Root fertilizer N concentrations accounted for an average of $17 \%$ of total $\mathrm{N}$ taken up averaging $5.2 \mathrm{~kg} \mathrm{~N} / \mathrm{ha}$ (data not shown).

Shoot: root fertilizer $\mathrm{N}$ partitioning was significantly different between runs. In Run 1, temperature regimen significantly affected shoot: root $\mathrm{N}$ partitioning $(P<0.001)$ and $40 \%$ of ${ }^{15} \mathrm{~N}$ was partitioned to the roots in November compared with $13 \%$ and $12 \%$ in October and September, respectively. In Run 2, temperature regimen did not significantly affect shoot:root fertilizer $\mathrm{N}$ partitioning $(P=0.14)$ with all temperature regimens accumulating between $14 \%$ and $17 \%$ of fertilizer $\mathrm{N}$ in the roots.

Net ecosystem $\mathrm{CO}_{2}$ exchange was only affected by temperature regimen and species with no effect of $\mathrm{N}$ rate or any interactions (Table 7). NEE increased as temperature regimen decreased (Table 8). Statistically, creeping bentgrass had greater NEE during each temperature regimen compared with kentucky bluegrass, although the difference was less than $2 \%$.

\section{Discussion}

The lack of growth response of the coolseason grasses in October and November temperature regimens is consistent with previous research suggesting a minimal shoot growth response to $\mathrm{N}$ in temperatures below 
$10{ }^{\circ} \mathrm{C}$ (Powell et al., 1967; Wilkinson and Duff, 1972). As noted in the introduction, the convention for the past several decades has been to recommend $\mathrm{N}$ application in the fall. Our results indicate that actively growing turfgrasses absorb applied $\mathrm{N}$ very efficiently $(65 \%$ to $83 \%$ ) regardless of $\mathrm{N}$ rate (Fig. 1). Fertilizing when shoot growth becomes unresponsive to $\mathrm{N}$ application still was relatively efficient ( $46 \%$ to $72 \%$ ), especially at the lowest application rate. However, fertilizing when air temperatures approach $0^{\circ} \mathrm{C}$ resulted in low and

Table 6. Root biomass as affected by temperature regimen and turfgrass species. ${ }^{\mathrm{z}}$

\begin{tabular}{cccc}
\hline Timing & $\begin{array}{c}\text { Creeping } \\
\text { bentgrass }\end{array}$ & $\begin{array}{c}\text { Kentucky } \\
\text { bluegrass }\end{array}$ & $\begin{array}{c}\text { Annual } \\
\text { bluegrass }\end{array}$ \\
\hline Run 1 & & $\begin{array}{c}g \cdot m^{-2} \\
118 \mathrm{D}\end{array}$ & $179 \mathrm{BC}$ \\
Sept. & $297 \mathrm{~A}$ & $145 \mathrm{CD}$ & $149 \mathrm{CD}$ \\
Oct. & $290 \mathrm{~A}$ & $210 \mathrm{~B}$ & $284 \mathrm{~A}$ \\
Nov. & $341 \mathrm{~A}$ & & \\
& & & \\
Run 2 & & $192 \mathrm{D}$ & $205 \mathrm{D}$ \\
Sept. & $297 \mathrm{AB}$ & $220 \mathrm{CD}$ & $253 \mathrm{BCD}$ \\
Oct. & $311 \mathrm{AB}$ & $133 \mathrm{E}$ & $277 \mathrm{ABC}$ \\
Nov. & $365 \mathrm{~A}$ &
\end{tabular}

zTemperature regimens correspond to 15 Sept., 15 Oct., and 15 Nov. in Madison, WI. Roots were harvested $10 \mathrm{~d}$ after nitrogen application. Different letters within runs indicate statistical significance of $\log$ transformed values at the 0.05 level according to Tukey's honestly significant difference. variable uptake of applied N (15\% to $60 \%)$. These results build on the work of Bowman et al. (1989), who quantified the uptake potential of cool-season grasses by monitoring the rapid depletion in the soil of applied fertilizer. That study demonstrated the $\mathrm{N}$ uptake potential under ideal growing conditions in the field, whereas our study demonstrated the extent of $\mathrm{N}$ uptake under cool temperatures.

Root growth and NEE were the only measured parameters for which $\mathrm{N}$ rate was not a consistently significant main effect (Tables 2 and 7). These results suggest that although root growth may increase in response to cooler soil temperatures (Tables 5 and 6), this trend is not stimulated further through $\mathrm{N}$ fertilization. Our finding is consistent with previous research (Mangiafico and Guillard, 2006; Powell et al., 1967). It may not be surprising that we found few differences in root growth among the treatments because only $10 \mathrm{~d}$ passed between application and harvest. Although additional longer-term or field research would be desirable to test the hypothesis that fall $\mathrm{N}$ does not affect root growth, our data preliminarily indicate that $\mathrm{N}$ applied at these rates in these temperature regimens has little effect on short-term root growth.

The absence of an $\mathrm{N}$ effect on NEE further supports the hypothesis that $\mathrm{N}$ does not stimulate root growth when shoots are inhibited by cool temperatures. NEE was found to increase as temperature decreased, which matched the trend of increased root growth in cold temperatures in Run 1. Photosynthesis rates of coolseason turfgrasses at low temperatures are not well publicized. Our NEE rates were $\approx 75 \%$ lower than those published for creeping bentgrass growing in sand at optimal shoot growth temperatures (Pote et al., 2006). The daily $P A R$ supplied in our controlled environments was midway between what our region experiences in September and October (Stier and Gardner, 2008), which generally seems to be sufficient to maintain high-quality turf. The relatively cool temperatures in our study may have limited regeneration of Ribulose-1, 5-bisphosphate (RuBP), whereas the slight increase observed between September and November conditions could have been the result of enhanced RuBisCO selectivity for $\mathrm{CO}_{2}$ (Sage and Kubien, 2007). Additional information on the interaction of photosynthetic rates, carbohydrate, and $\mathrm{N}$ uptake and metabolism of cool-season turfgrasses could help explain winter survival and regrowth in spring.

We were unable to conclusively document the effect of $\mathrm{N}$ partitioning between shoots and roots for $\mathrm{N}$ applications in cold temperatures. It appears that shoot:root partitioning was not significantly different between the September and October regimens, but in Run 1, strong partitioning of $\mathrm{N}$ to roots was observed, whereas in Run 2, this did not occur.
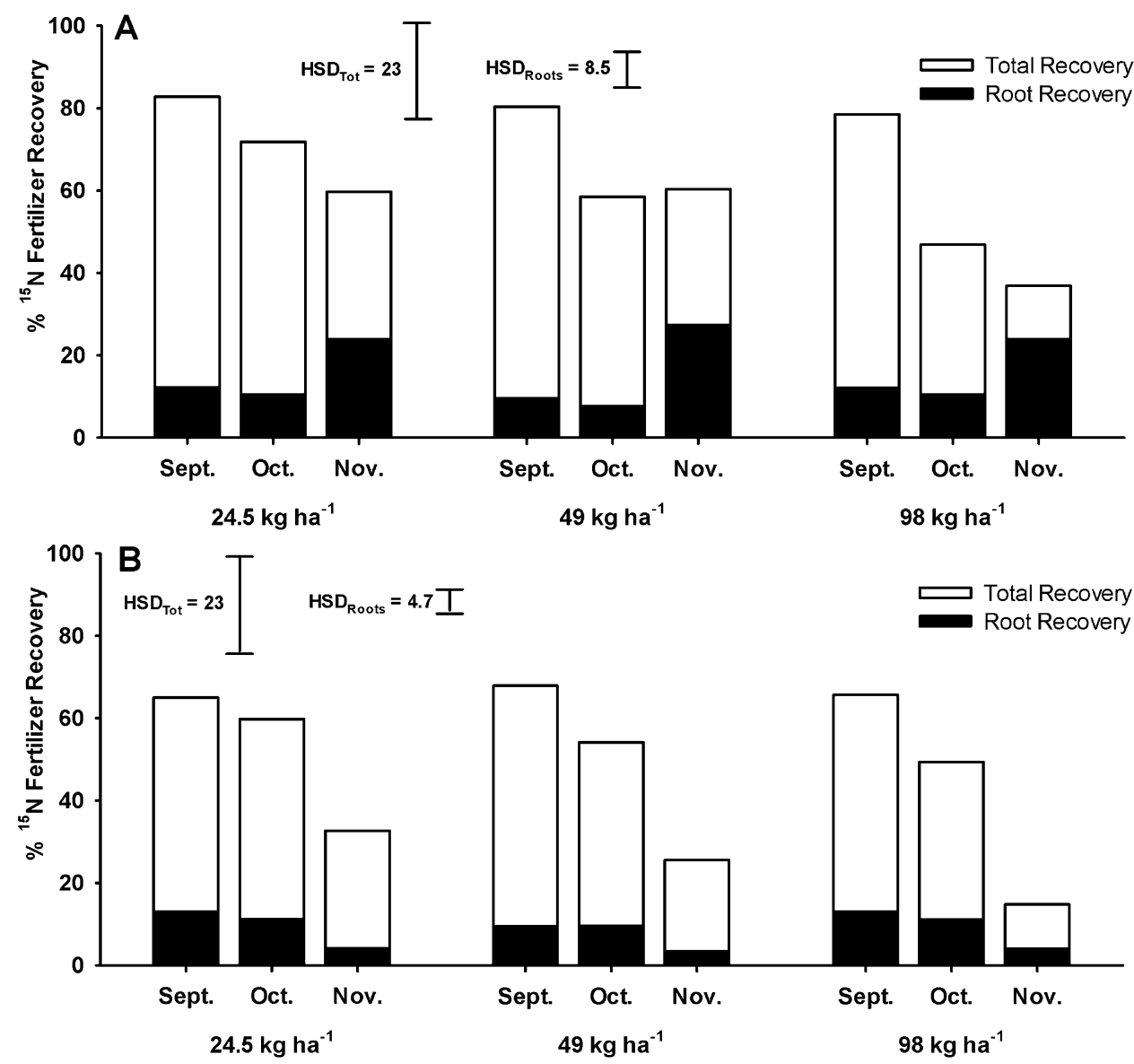

Fig. 1. Effect of temperature regimen and nitrogen application rate on ${ }^{15} \mathrm{~N}$ fertilizer recovery in roots and roots + verdure (total) for (A) Run 1 and (B) Run 2 . Roots and verdure were harvested $10 \mathrm{~d}$ after nitrogen application. Temperature regimens correspond to 15 Sept., 15 Oct., and 15 Nov. in Madison, WI. 
Table 7. $P$ values from analysis of variance for treatment effects on net ecosystem exchange rate. $^{z}$

\begin{tabular}{lrc}
\hline $\begin{array}{l}\text { Source of } \\
\text { variation }\end{array}$ & df & $\begin{array}{c}\text { Net ecosystem } \\
\text { exchange } \\
\left(\mu \mathrm{mol} \cdot \mathrm{m}^{-2} \cdot \mathrm{sec}^{-1}\right)\end{array}$ \\
\hline Temperature (T) & 2 & $<0.001^{* * *}$ \\
N Rate $(\mathrm{N})$ & 3 & 0.168 \\
Species $(\mathrm{S})$ & 2 & $<0.001 * * *$ \\
$\mathrm{~T} \times \mathrm{N}$ & 6 & 0.468 \\
$\mathrm{~T} \times \mathrm{S}$ & 4 & 0.522 \\
$\mathrm{~N} \times \mathrm{S}$ & 6 & 0.835 \\
$\mathrm{~T} \times \mathrm{N} \times \mathrm{S}$ & 12 & 0.526 \\
\hline
\end{tabular}

zThree temperature regimens correspond to 15 Sept., 15 Oct., and 15 Nov. in Madison, WI. Four nitrogen (N) rates were applied $\left(0,25,49\right.$, and $\left.98 \mathrm{~kg} \cdot \mathrm{ha}^{-1}\right)$ to three turfgrass species (creeping bentgrass, kentucky bluegrass, annual bluegrass)

***Significant at the $0.001 P$ level.

Table 8. Effect of temperature regimen and species on net ecosystem exchange rates. ${ }^{\mathrm{z}}$

\begin{tabular}{ccc}
\hline Main Effect & \multicolumn{1}{c}{ Level } & $\begin{array}{c}\text { Log of net } \\
\text { ecosystem } \\
\text { exchange } \\
\left(\mu \mathrm{mol} \cdot \mathrm{m}^{-2} \cdot \mathrm{sec}^{-1}\right)\end{array}$ \\
\hline $\begin{array}{c}\text { Temperature } \\
\text { regimen }\end{array}$ & 15 Sept. & $2.01 \mathrm{C}$ \\
& 15 Oct. & $2.07 \mathrm{~B}$ \\
& 15 Nov. & $2.21 \mathrm{~A}$ \\
Species & $\begin{array}{c}\text { Creeping } \\
\text { bentgrass }\end{array}$ & $2.12 \mathrm{~A}$ \\
& $\begin{array}{c}\text { Kentucky } \\
\text { bluegrass } \\
\text { Annual bluegrass }\end{array}$ & $2.11 \mathrm{AB}$ \\
\hline
\end{tabular}

${ }^{\mathrm{z}}$ Three temperature regimens correspond to $15 \mathrm{Sept}$. 15 Oct., and 15 Nov. in Madison, WI. Different letters within main effects indicate statistical significance at the 0.05 level according to Tukey's honestly significant difference.

Our results suggest that some of the widely held views on the importance of fall fertilization may not be as well understood as thought. The $\mathrm{N}$ uptake capacity of creeping bentgrass, annual bluegrass, and kentucky bluegrass declines substantially as temperatures decrease, although $\mathrm{N}$ uptake potential appears to be relatively high near the time after shoot growth stops. Waiting after this period greatly reduces $\mathrm{N}$ uptake potential. Because of the increased risk of $\mathrm{N}$ loss during the fall in humid, temperate regions resulting from seasonally high rates of precipitation and low rates of ET, agronomic recommendations for late-fall fertilization need to be re-evaluated. Additional field research is required to confirm the results of this controlled environment evaluation.

\section{Literature Cited}

Baird, J.H. 2007. Soil fertility and turfgrass nutrition 101: Some important concepts you migh have missed in or outside of the classroom. USGA Green Sec. Rec. 45:1-8.

Bauer, S., D. Lloyd, B.P. Horgan, and D.J. Soldat. 2012. Agronomic and physiological responses of cool-season turfgrass to fall-applied nitrogen. Crop Sci. 52, doi: 10.2135/cropsci2011.03.0124.

Bowman, D.C. 2003. Daily vs. periodic nitrogen addition affects growth and tissue nitrogen in perennial ryegrass turf. Crop Sci. 43:631-638.

Bowman, D.C., J.L. Paul, W.B. Davis, and S.H. Nelson. 1989. Rapid depletion of nitrogen applied to Kentucky bluegrass turf. J. Amer. Soc. Hort. Sci. 114:229-233.

Danneberger, K. 2006. Fall fertilization is fundamental. Golfdom. 1 July 2006. <http://www. golfdom.com/golfdom/article/articleDetail.jsp? id $=35316>$.

Dubey, R.S. and M. Pessarakli. 2002. Nitrogen absorption under stress, p. 637-655. In: Pessarakli, M. (ed.). Handbook of plant and crop physiology. 2nd Ed. Marcel Dekker, Inc., New York, NY.

Frank, K.W., J.R. Crum, R.N. Calhoun, and K.M. O'Reilly. 2006. The fate of nitrogen applied to a mature kentucky bluegrass turf. Crop Sci. 46:209-215.

Green Section Staff. 2004. Putting green guidelines. U.S. Golf Association (USDA). 12 Feb. 2009 $<$ http://www.usga.org/turf/course_construction/ green_articles/putting_green_guidelines.html $>$.

Hanson, A.A. and F.V. Juska. 1961. Winter root activity in kentucky bluegrass (Poa pratensis L.). Agron. J. 53:372-374.

Koski, A.J. 1988. Late-season nitrogen fertilization: What we do and do not know. USGA Green Sec. Rec. 26:8-11.

Kreuser, W.C., M.P. Fish, D.J. Soldat, and S. Bauer 2011. Removing sand from putting green clipping samples substantially reduces clipping weight measurement error. Crop Sci. 51:1268-1273.

Kussow, W.R. 1988. Fall fertilization of cool-season turfgrasses: When the leaves begin to drop, coolseason grasses can use a nutritional boost to speed their recovery from the stress of summer. Golf Course Manage. 56:20, 22, 26, 28, 30.

Ledeboer, F.B. and C.R. Skogley. 1973. Effects of various nitrogen sources, timing, and rates on quality and growth rate of cool-season turfgrasses. Agron. J. 65:243-246.

Liu, H., C.M. Baldwin, H. Luo, and M. Pessarakli. 2008. Enhancing turfgrass nitrogen use under stresses, p. 557-581. In: Pessarakli, M. (ed.).
Handbook of turfgrass management and physiology. Taylor and Francis Group, LLC, Boca Raton, Fl.

Mangiafico, S.S. and K. Guillard. 2006. Fall fertilization timing effects on nitrate leaching and turfgrass color and growth. J. Environ. Qual. 35:163-171.

Miltner, E.D., B.E. Branham, E.A. Paul, and P.E Rieke. 1996. Leaching and mass balance of ${ }^{15} \mathrm{~N}$-labeled urea applied to a kentucky bluegrass turf. Crop Sci. 36:1427-1433.

Miltner, E.D., G.K. Stahnke, W.J. Johnston, and C.T. Golob. 2004. Late fall and winter nitrogen fertilization and turfgrass in two pacific northwest climates. HortScience 39:1745-1749.

Moon, J.W., Jr., D.M. Kopec, E. Fallahi, C.F. Mancino, D.C. Slack, and K. Jordan. 1990. Limitations of photosynthesis in Lolium perenne after chilling. J. Amer. Soc. Hort. Sci. 115:478-481.

Moore, R.W., N.E. Christians, and M.L. Agnew. 1996. Response of three Kentucky bluegrass cultivars to sprayable nitrogen fertilizer programs. Crop Sci. 36:1296-1301

Pote, J., Z. Wang, and B. Huang. 2006. Timing and temperature of physiological decline for creeping bentgrass. J. Amer. Soc. Hort. Sci. 131:608-615.

Powell, A.J., R.E. Blaser, and R.E. Schmidt. 1967. Physiological and color aspects of turfgrasses with fall and winter nitrogen. Agron. J. 59:303307.

Reicher, Z. 2005. November fertilization is money in the bank. Purdue University, Agronomy Department, Turfgrass Science Program. 22 Oct 2007. <http://www.agry.purdue.edu/turf/tips/2005/ novn1024.htm>.

Rieke, P.E. 1997. The view from MSU: Late fall fertilization philosophies. On Course 51:20,22, 24, 34.

Rieke, P.E. 1998. Cool-season turf benefits from fall fertilization. Grounds Maint. 33:22-24.

Sage, R.F. and D.S. Kubien. 2007. The temperature response of $\mathrm{C}_{3}$ and $\mathrm{C}_{4}$ photosynthesis. Plant Cell Environ. 30:1086-1106.

Snow, J.T. 1982. Early spring greenup-Don't push it. USGA Green Sec. Rec. 20:6-8.

Stier, J.C. and D.S. Gardner. 2008. Shade stress and management, p. 447-472. In: Pessarakli, M. (ed.). Handbook of turfgrass physiology and management. CRC Press, Taylor \& Francis Group, Boca Raton, FL.

Walker, K.S., C.A. Bigelow, D.R. Smith, G.E. Van Scoyoc, and Z. Reicher. 2007. Aboveground responses of cool-season lawn species to nitrogen rates and application timings. Crop Sci 47:1225-1236.

Wehner, D.J., J.E. Haley, and D.L. Martin. 1988. Late fall fertilization of kentucky bluegrass. Agron. J. 80:466-471.

Wilkinson, J.F. and D.T. Duff. 1972. Effects of fall fertilization on cold resistance, color, and growth of kentucky bluegrass. Agron. J. 64:345-348. 